\begin{tabular}{l|l} 
Academic & $\begin{array}{l}\text { Institut Agama Islam Negeri (IAIN) Curup, Indonesia } \\
\text { Journal of } \\
\text { Islamic Studies }\end{array}$ \\
ISSN 2580-3174, (p); 2580-3190 (e) \\
volume 6, number 1, 2021 I page: 25-48 \\
DOI: http://doi.org/10.29240/ajis.v6i1.2555
\end{tabular}

\title{
The Roles of Islamic Educational Institutions in Religious Moderation
}

\author{
Muhammad Idris, Alven Putra \\ Institut Agama Islam Negeri (IAIN) Curup, Indoneisa \\ mudris81@gmail.com, alvenputra1708@gmail.com
}

\begin{abstract}
Indonesia is a country which is rich in differences in ethnicity, race, skin color, and religion. Islamic education institutions, as part of many other institutions, must show their existence in dealing with differences through fostering religious moderation among students. This study aims at revealing the participation of Islamic education institutions in religious moderation and what Islamic educational institutions do to build religious moderation in Indonesia. This study uses a descriptive method with a library research approach. In so doing, this study is conducted by reading various references related to the discussed issues. The findings uncover that Islamic educational institutions have several roles in terms of religious moderation, namely: first, educational institutions have a role in formulating or revising educational goals; second, educational institutions have a role in providing guidance through educators; third, educational institutions have a role in synergizing religious moderation with materials/curriculum and learning processes; and fourth, educational institutions have a role in making students familiar with the applications of religious moderation through the school environment. The things that Islamic education institutions can do towards religious moderation are: first, formulating educational goals based on religious moderation; second, direct coaching through teachers; third, the integration of religious moderation in materials/curriculum in learning subjects; and fourth, synergizing all school members in habituating religious moderation behavior.
\end{abstract}

Keywords: Religious Moderation, Institutions, Education

\section{Introduction}

On the one hand, Indonesia is grateful to Allah SWT for blessing it with a diverse range of ethnicities, religions, races, and cultures. This variety is linked to the motto "Bhinneka Tunggal Ika," which means that despite differences, it remains one. Indonesia's diversity must be able to function as an "integrating force" that binds society together ${ }^{1}$. On the other hand, the existing

${ }^{1}$ Agus Akhmadi, “Moderasi Beragama dalam Keragaman Islam," Inovasi-Jurnal Diklat Keagamaan 13, no. 2 (April 23, 2019): 45. 
diversity is unquestionably a test for the Indonesian nation. Why not? Frequent violence in the name of religion, ethnicity, race, and culture is unavoidable. Hatred, violence, and vandalism occur frequently, possibly as a result of minor issues such as offenses between groups. If not managed properly, the diversity of ethnicities, religions, races, and cultures will become a ticking time bomb that, when the time comes, will explode and destroy the society's established order.

There are a few incidences that have stayed with us and tarnished the image of the Indonesian people who uphold the values of unity and tolerance. The incidences were attributed to the tolikara (Papua) incidence during the Eid al-Fitr $1436 \mathrm{H}$ celebration, the burning of the church in Aceh Singkil, and the Paris, France bombing, which killed more than one hundred people. ${ }^{2}$ The suicide bombing in Surabaya demonstrates how easily offenses between ethnic groups, races, cultures, and, especially, religions can occur. Violence in the name of race, ethnicity, culture, and, especially, religion gives the impression that religion justifies killing, burning, destroying, and other atrocities. Religion, in fact, teaches all of its adherents (followers) to love, appreciate, and respect others. $^{3}$

Tolerance is a tenet of every religion. As the most widely practiced religion in Indonesia, Islam has rules that benefit Muslims ${ }^{4}$. These rules undoubtedly have a strong relationship with the Indonesian state's mission of religious moderation. According to Edi's book, Islam's laws are based on five principles: maintaining religion (hifdz al-din), guarding the soul (hifdz al-nafs), maintaining reason (hifdz al 'al), guarding offspring (hifdzl al-nasl), and safeguarding property (hifdz al mal). ${ }^{5}$ A partial understanding of religion will lead the followers to acting in ways that contradict to the religious teachings.

A comprehensive understanding of religion is required to avoid partial religious understanding. A comprehensive understanding of religion is a method of study that seeks to understand Islamic teachings in holistic and

2 “TNI Dan Polisi Magelang Jaga Gereja sebagai Antisipasi Dampak Tolikara," Tribun Jogja, July 25, 2015, https://jogja.tribunnews.com/2015/07/25/tni-dan-polisimagelang-jaga-gereja-sebagai-antisipasi-dampak-tolikara.

3 Nurkholis Madjid, Pluralitas Agama; Kerukunan Agama Dalam Keragaman (Jakarta: Kompas Nusantara, 2001), 38-39.

${ }^{4}$ Samsul Ar, "Peran Guru Agama Dalam Menanamkan Moderasi Beragama," AlIrfan: Journal of Arabic Literature and Islamic Studies 3, no. 1 (March 27, 2020): 39, doi:10.36835/al-irfan.v3i1.3715.

${ }^{5}$ Edi, Ah, Iyubenu, Hate Speech dalam Islam, Kedaulatan Rakyat, 13 November 2015, p. 12 
complete ways ${ }^{6}$. It can accommodate and straighten out ideas that are contrary to the concept of the common good, especially for the survival of religious communities and the maintenance of national unity and integrity, with this comprehensive understanding of religion. As a result, any institution in Indonesia, formal or informal, has the responsibility and role of raising religious awareness in a comprehensive manner and can kill the seeds of dispute. An educational institution is one of the institutions that has many aspects and capabilities in terms of management.

Educational institutions play an important strategic role in religious moderation because they can break the chain of violence in the name of religion $^{7}$. It is the leading sector in fostering religious moderation through various approaches in teacher education institutions. One of the approaches which can be adopted by educational institutions to guide religious moderation is an educative approach.

The educative approach is a form of mutual communication between two parties ${ }^{8}$. Harizal also explained that an interaction containing education is one that has the conscious goal of educating or leading students to maturity 9 . An educational approach can be implemented in peaceful education that is integrated into the school curriculum, constructive conflict resolution training, mediation and negotiation by peers as a collaborative effort to transform the Indonesian nation into a nation of reconciliation ${ }^{10}$.

The religious moderation brought into this paper is aligned with one delineated by Fahruddin in Akhmadi. In this regard, religious moderation means balance, in the middle, is not excessive, does not truth claim, does not use extreme theological legitimacy which admits that one's group is the most correct, is neutral, and is not affiliated with any political party ${ }^{11}$. Fahruddin's concept of religious moderation is an accomplishment that must be prioritized in order to build a safe and peaceful Indonesian nation.

6 Sulthan Syahrir, "Metode Studi Islam Komprehensif Dan Implikasinya Terhadap Corak Pemikiran Aliran-Aliran Dalam Islam," Analisis: Jurnal Studi Keislaman 19, no. 2 (2019): 347, doi:10.24042/ajsk.v19i2.3616.

${ }^{7} \mathrm{Ar}$, "Peran Guru Agama Dalam Menanamkan Moderasi Beragama," 39.

8 Harizal Anhar, "Interaksi Edukatif Menurut Pemikiran Al-Ghazali," Jurnal Ilmiah Islam Futura 13, no. 1 (August 1, 2013): 31, doi:10.22373/jiif.v13i1.570.

${ }^{9}$ Ibid.,

10 Ibid.,

${ }^{11}$ Akhmadi, “Moderasi Beragama dalam Keragaman Islam," 51. 
Based on the description above, educational institutions are deemed necessary to demonstrate their roles and fangs in fostering religious moderation as institutions or places to carry out various types of education. If an educational institution's employees are educated citizens ranging from school principals, teachers, employees, and students, they will become members of the community after they return from school. As a result, the author describes the role of Islamic educational institutions in religious moderation in this paper. In this case, the role referred to is institutions' participation in fostering religious moderation and what institutions can do to promote religious moderation.

The study in this paper focuses on the role of Islamic educational institutions in fostering religious moderation.

\section{The Concept of Religious Moderation}

Literally, moderation means "moderate" which is the inverse of the word extreme or excessive in addressing differences and diversity. In Arabic, the term moderation is commonly known from the term al-wasathhiyah. The term al-wasathhiyah appears in Surat al Baqarah, verse 143 of the Qur'an. In this verse, the word al-Wasath means "best and most perfect." According to a hadith, the best way in dealing with a problem is to take a position in the middle. The foregoing is attributed to the way of coping with a problem. ${ }^{12}$

Moderation is derived from the Latin word moderatio, which means "medium" that is not excessive or lacking, as well as self-control. ${ }^{13}$

Terminologically, religious moderation, as defined by the team of the Ministry of Religion of the Republic of Indonesia, has the meaning of pluralism and is absolutely necessary in various conditions of a pluralistic nation by providing comprehensive religious teaching that can represent everyone towards flexible teachings without leaving the texts (al-Quran and Hadith) and the importance of reasoning as a mental tool to solve every existing problem. ${ }^{14}$

12 Darlis Dawing, "Mengusung Moderasi Islam Di Tengah Masyarakat Multikultural," Rausyan Fikr: Jurnal Studi Ilmu Ushuluddin Dan Filsafat 13, no. 2 (2017): 225-55, doi:10.24239/rsy.v13i2.266.

13 Kementerian Agama RI, Moderasi Beragama (Jakarta: Balitbang dan Diklat Kemenag RI, 2019), 15-17.

${ }^{14}$ Ahmad Fauzi, "Moderasi Islam, Untuk Peradaban Dan Kemanusiaan," JURNAL ISLAM NUSANTARA 2, no. 2 (December 30, 2018): 233, doi:10.33852/jurnalin.v2i2.101. 33 
To be moderate in Islamic thought is to promote tolerance for differences. Diversity is accepted through openness (inclusivism) in terms of differences in both schools and religions. Disagreements do not prevent us from cooperating in accordance with humanitarian principles ${ }^{15}$. Believing in Islam's true religion does not obligate you to insult other people's religions. In so doing, there is brotherhood and unity, as there was in Medina under the leadership of the Prophet Muhammad (PBUH).

Hashim Kamali emphasized that the word "moderate" cannot be separated from two other keywords, namely "balance" and "justice". "Moderate" does not mean that we compromise with the principles (ushuliyah) of religious teachings that are believed to be tolerant towards people of other religions. "Moderate" means ".. confidence, right balancing, and justice ,,". ${ }^{16}$. Without balance and justice, the call for religious moderation will be ineffective. Thus, "moderate" means that each of them must not be extreme, both of them must approach and find common ground.

In relation to the term "extreme" above, Edy Sutrisno explained that in terms of the actualization of religious moderation, as long as the extremity above is on one side, then religious intolerance and conflict will inevitably remain as "embers in the husks," which could explode at any time, especially if triggered by a political axis. As Hashim Kamali stated, "moderation is about pulling together the disparate centers than want to find a proper balance wherein people of different cultures, religions and politics listen to each other and learn how to work out their differences"17

Yusuf al Qardawi defines several synonyms for wasathiyah, including Tawadzun, I'tidal, Ta'adul, and Istiqamah. Meanwhile, wasathiyah, according to Khaled Abu el Fadl, is a middle-of-the-road understanding, one that is neither extreme to the right nor extreme to the left. ${ }^{18}$.

Abdurrahman Wahid also concluded that moderation promotes efforts to achieve social justice, also known as maslahah al'ammah. ${ }^{19}$ Wasathiyyah is the harmony of ukhrawi and worldly life, soul and body, aql and naql, individual and society, ideas and realities, religion and state, old and new,

\footnotetext{
15 Dawing, "Mengusung Moderasi Islam Di Tengah Masyarakat Multikultural."

16 Mohammad Hashim Kamali, The Middle Path of Moderation in Islam (Oxford: University Press, 2015), 14.

17 Ibid.,

18Zuhairi Misrawi, Hadratussyaikh Hasyim Asy'ari Moderasi, Keutamaan Dan Kebangsaan (Jakarta: PT. Kompas Media Nusantara, 2010), 13.

${ }^{19}$ Ibid., 14.
} 
religion and science, and modernity and tradition, accompanied by the principle of "not lacking and excess." 20 .

The word wasathiya appears several times in the Qur'an, all of which have a meaning in the middle or between two ends ${ }^{21}$, namely first, in Surat alBaqarah verse 143 of the Qur'an. "And so (also) have we made you (Muslims) the just and chosen people, that you may witness to human deeds and that the Messenger (Muhammad) may witness your deeds. Second, al-Quran Surat alBaqarah verse 238; third, al-Quran Surat al-Maidah verse 89, fourth, al-Quran Surat al-Qalam verse 28; and finally, al-Quran Surat al'adiyat verse 4-5.

Based on the above definitions of moderation, it is possible to conclude that religious moderation is a method used by a religious person to achieve peace by promoting the attitude of tolerance, namely performing religiosity openly without seeing the differences.

\section{Indicators of Religious Moderation}

The understood indicators of religious moderation are indications of someone who is said to be religiously moderate. According to Quraish Shihab's opinion, as quoted by Zamimah, 2018 in Muhammad Fahri, there are several pillars or indicators of religious moderation, namely: justice, balance, and tolerance ${ }^{22}$.

The first is justice. The definition of justice is "equality in rights." A person who walks straight and stances uses only one measurement, never two. ${ }^{23}$ Because of the existence of equality, someone will be able to act fairly, not taking sides with one of the disputants. Justice also entails being able to act in accordance with its provisions rather than acting on your own volition. When a person acts according to his or her own will, regardless of the will of others, the action will cause friction. The friction that occurs will lead to the extreme, and the extreme's end result will be intolerance.

The second is balance. Balance, according to Quraiys Shihab, can be found in a group of various parts that lead to a specific goal, as long as the conditions and levels are met by each part. With the accumulation of these conditions, the group will be able to survive and run in order to fulfill the

20 Muhammad Quraysh Shihab, Wasathiyyah; Wawasan Islam Tentang Moderasi Beragama (Tangerang: Lentera Hati, 2019), 43.

21 Ibid., 4.

22 Mohamad Fahri and Ahmad Zainuri, "Moderasi Beragama Di Indonesia," Intizar 25, no. 2 (2019): 95-100, doi:10.19109/intizar.v25i2.5640.

23 Ibid., 
purpose of its presence. Equilibrium does not necessitate the equality of content and conditions in order for all parts of the unit to be balanced. A part may be small or large, with small and large determined by the function expected of $\mathrm{it}^{24}$.

The third is tolerance. According to Qurays Shihab, tolerance is the indicator for addition and subtraction which are still acceptable. Tolerance is a deviation that must be done in order for it not to be done; in other words, it is a deviation that can still be justified.

The concept of wasathiyah, which is the origin of the meaning of moderation, will be a dividing line between two opposing things, also known as a mediator. It is claimed that the mediator does not justify the existence of radical ideas in religion and, on the contrary, does not justify any attempt to disregard the contents of the Koran as the primary legal basis. As a result, the washatiyah concept tends to mean tolerance and is not ambiguous when it comes to interpreting Islamic teachings.

Ammar Sukri and Yusuf Qardawi, in Afifuddin Muhajir, match the word wasathiyyah with three things which are the main characteristics of Islam. These characteristics are 1) tawasuth (middle), 2) ta'adul (fair), and 3) tawazun (balanced). The three equivalents are put together in one term, namely wasathiyyah or in the other language called moderation. ${ }^{25}$ The three views are:

The first is tawasuth. According to Qurays Shihab, the meaning of tawasuth is often regarded as having no assertiveness in attitude, as it does not encourage people to strive for the ultimate in worship, knowledge, wealth, and so on. This tawasuth, however, does not imply that it is unsure about something, as in a passive neutral attitude, nor that it is a mathematical intermediary, as Greek philosophers believed. Although gentleness is one indicator of moderation, but in this sense, it does not mean that it is not permissible to confront the problem firmly.

The second is ta'adul. Ta'adul is to put something in its proper place. ${ }^{26}$ Being fair is Allah's commandment. There are numerous verses and hadiths that teach us to be fair. Scholars divide the meaning of fair into four categories: 1) fair in the same sense (equality of rights; Qs. An-nisa verse 4), 2) fair in the

24 Ibid.,

${ }^{25}$ Afifuddin Muhajir, Membangun Nalar Islam Moderat; Kajian Metodologis (Situbondo: Tanwirul Afkar, 2018), 1.

${ }^{26}$ Shihab, Wasathiyyah; Wawasan Islam Tentang Moderasi Beragama, xi. 
sense of balance, 3) fair in the sense of paying attention to individual rights and share rights with each of the owners, and 4) fair which is ordained to God because God maintains the fairness of the continuation of life. God's fairness or justice is essentially His grace and goodness. ${ }^{27}$

The third is tawazzun, wasathiyyah also means tawazzun, which means the middle path, such as the balance between spirit and body, the world and the hereafter, individuals and society, ideals and reality, and so on. For example, the Islamic concept of livelihood is a happy medium between being frugal and wasteful, liberal and conservative. ${ }^{28}$ In the context of balance, the Prophet encouraged his people to overreact.

Muchlish M. Hanavi also found, that the characteristics or indicators of moderation (al wasathiyyah) are: first, understanding reality (fiqh al-waaqi), meaning that all actions should realistically consider the contexts of mashlahat and mudharat, so as not to want to do something (mashlahat) which brings greater harm; second, understanding the fiqh of priority (fiqh al awlawiyyat), which means that a moderate attitude requires a person not to prioritize things that are sunnah and leave the obligatory; third, understanding the sunnatullah in creation; fourth, providing convenience to others in religion; fifth, understanding religious texts comprehensively; and sixth, being open to the outside world, promoting dialogues, and being tolerant. ${ }^{29}$

\section{The Concept of Islamic Education Institutions}

The meaning of educational institutions can be seen in terms of etymology and terminology. Etymologically, an institution is a body or organization. In the Big Indonesian Dictionary, it is stated that an institution is an agency or organization whose purpose is to carry out a scientific investigation or conduct an effort. ${ }^{30}$ In English, an institution is called an institute (in the physical sense), which means a means or organization to achieve certain goals, while an institution in a non-physical or abstract sense is called an Institution, which means a system of norms to meet needs. Institutions in the physical sense are also called buildings, and institutions in non-physical terms are also called institutions.

27 Syafrudin, Paradigma Tafsir Tekstual Dan Kontekstual; Usaha Memaknai Kembali Pesan al Quran (Yogyakarta: Pustaka Pelajar, 2009), 104-5.

${ }^{28}$ Muhajir, Membangun Nalar Islam Moderat; Kajian Metodologis, 5.

${ }^{29}$ Muchlis M. Hanafi, Moderasi Islam (Ciputat: Ikatan Alumni al Azhar dan Pusat Studi al Quran (PSQ), 2013), 21-27.

30 Pusat Bahasa Departemen Pendidikan Nasional, Kamus Besar Bahasa Indonesia (Jakarta: PT. Gramedia, 2008), 808. 
In terms of terminology, Ramayulis cited Hasan Langgulung and stated that educational institutions are a system of abstract regulations, a concept that contains codes, norms, ideologies, and so on whether written or not, including material completeness and symbolic organization; human groups consisting of individuals who are formed intentionally or unintentionally to achieve certain goals and the like, and the places where the group implements these regulations are: mosques, schools, kuttabs, and so on. ${ }^{31}$

According to Hasbullah, an Islamic education institution is a place where the Islamic education process takes place concurrently with the cultural process. $^{32}$ Because it always refers to and responds to the needs of the community, an Islamic education institution is a subsystem of a nation; otherwise, social and cultural gaps will arise, becoming a source of conflict. This chasm gives rise to an educational crisis, the severity of which varies according to the level or level of community needs. As a result, all Islamic educational institutions must be in accordance with the community's guidance and aspirations because it will be very difficult to achieve progress and development if this is not done.

Islamic education institutions are the result of community-initiated ideas that are based on, driven by, and developed by the Islamic spirit (alQuran and al-Sunnah). Islamic educational institutions, which have been around for a long time, are educational institutions that grow and develop in tandem with Islamic life in general. Islamic educational institutions are not rigid and frozen institutions, but rather flexible educational institutions that develop in accordance with the will of time and place. As a result, Islamic educational institutions are divided into three parts, as seen from the aspect of the person in charge:

\section{Informal Institutions of Islamic Education (family)}

Informal Islamic educational institutions are educational institutions with a focus on the family and society. ${ }^{33}$ In his writing, Ahmad Darlis explained that the family is the oldest center of education in Islam, and that family

${ }^{31}$ Ramayulis, Ilmu Pendidikan Islam (Jakarta: Kalam Mulia, 2011), 277.

32 Hasbullah, Kapita Selekta Pendidikan Islam (Jakarta: PT. Raja Grafindo, 1996), 38-39.

${ }^{33}$ Ibrahim Bafadhol, "Lembaga Pendidikan Islam di Indonesia," Edukasi Islami: Jurnal Pendidikan Islam 6, no. 11 (October 25, 2017): 14, doi:10.30868/ei.v6i11.95. 
education is as old as human civilization. ${ }^{34}$ The first and most important education is provided by the family. It is said first because a baby or child is first introduced to his or her surroundings and receives guidance from a family member. Meanwhile, it is said to be the first education because the family is regarded as the foundation stone for all subsequent developments. ${ }^{35}$

The family is society's smallest unit, and it is divided into two types based on size: the batih family (nuclear family), which consists of a father, mother, and child, and the extended family (extended family). ${ }^{36}$ In Islam, a family is referred to as usrah, 'ali, or nasb. Offspring (children, grandchildren), marriage (husband and wife), breastfeeding, and liberation can all be used to create a family. Economy, development, education, protection, and care, to name a few ${ }^{37}$. According to education experts, the first field of education is the family, and the educators are both parents, as parents are natural educators. ${ }^{38}$

According to the preceding viewpoint, the essence of the family is the father, mother, and child. In order to be free from the torments of hell, the family, father and mother, have a duty and responsibility to develop all of their strengths and potential. The Qur'an, Surat al-Tahrim verse 6, contains the duties and responsibilities of the family in education.

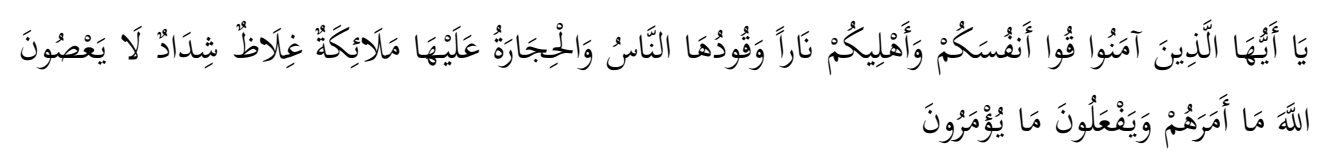

O you who believe, protect yourself and your family from the fire of hell whose fuel is people and stones; the keeper of the angels who are harsh, harsh, and do not disobey Allah against what He commands them and always do what is commanded.

Sidi Ghazalba classifies Informal Islamic education institutions (families) as primary education institutions, recognizing the strategic role that Informal Islamic education institutions (families) can play. In this educational

34 Ahmad Darlis, "Hakikat Pendidikan Islam: Telaah Terhadap Hubungan Pendidikan Informal, Non Formal Dan Formal," JURNAL TARBIYAH 24, no. 1 (August 21, 2017): 86, doi:10.30829/tar.v24i1.131.

35 Bafadhol, "Lembaga Pendidikan Islam di Indonesia."

${ }^{36}$ William J. Goode, Sosiologi Keluarga (Jakarta: Bumi Aksara, 2004), 11.

${ }^{37}$ Abdul Mujib, Ilmu Pendidikan Islam (Jakarta: Kencana, 2008), 226.

38 Nurlaili, "Metodologi Pendidikan Islam Formal-Informal (Analisa Pendidikan di Rumah dan Sekolah)," At-Ta'lim : Media Informasi Pendidikan Islam 12, no. 1 (March 1, 2019): 152-65, doi:10.29300/attalim.v12i1.1625. 
institution, there are parents, relatives, family members, and so on, and in addition to being an educator, there is also the person in charge. ${ }^{39}$

As a result, as the primary educational institution, cultivating, fostering, and developing a moderate religious attitude plays a critical role for the family.

\section{Formal Islamic Education Institutions (schools / madrasahs)}

Formal Islamic Education Institutions are educational institutions that are separate from informal educational institutions (family). Hadari Nawawi categorizes formal educational institutions such as schools and madrasas as educational institutions whose educational activities are carried out deliberately, planning, and systematically to assist children in developing their potential to carry out their duties as caliph. ${ }^{40}$ Whereas, Gazalba considers this formal education institution to be a type of secondary education, while the education is a professional teacher, the Republic of Indonesia has three educational institutions that are identified as Islamic educational institutions, namely pesantren, madrasah, and schools affiliated with Islamic organizations of all types and levels. In Indonesia, formal Islamic education institutions include: 1) Raudhatul Athfal. 2) Madrasah Ibtidaiyah (MI) or Islamic Elementary School (SDI), 3) Madrasah Tsanawiyah (MTs) or Islamic Junior High School (SMPI) or other names with similar meanings. 4) Higher education, including Islamic Religious College (STAI), State Islamic Institute (IAIN), State Islamic University (UIN), and other similar foundation or community-based institutions.

\section{Non-Formal Islamic Education Institutions}

Non-formal Islamic education institutions, when viewed in the context of their establishment, are broader education based on the community's intention and motivation to embody Islamic values ${ }^{41}$. Non-formal Islamic education institutions are regular institutions that do not adhere to rigid rules. Non-formal educational institutions, according to Abu Ahmadi, are all forms of education that are carried out deliberately, orderly, and planned outside of the

\footnotetext{
${ }^{39}$ Ramayulis, Ilmu Pendidikan Islam, 281-82.

${ }^{40}$ Abu Ahmadi and Nur Uhbiyati, Ilmu Pendidikan Islam (Jakarta: Rineka Cipta, 1991), 171-72.

41 Siti Romlah, "Sistem Penyelenggaraan Pendidikan Islam Non Formal Di Indonesia," Jurnal Studi Islam: Pancawahana 15, no. 1 (June 22, 2020): 1-14.
} 
activities of school institutions (formal educational institutions) while still cultivating the breath of Islam in the process of its implementation. ${ }^{42}$

Meanwhile, non-formal education institutions, as defined by Gampang Sari Limbong from citing Muhammad Dahrim's statement, are educational channels outside of formal education institutions that can be implemented in a structured and tiered manner. ${ }^{43}$ Furthermore, it is stated in the National Education System Law that non-formal education is provided for citizens who require educational services that serve as substitutes, enhancers, or complements

Non-formal educational institutions, as described above, serve to develop students' potential by emphasizing mastery of knowledge, skills, and the development of attitudes or personalities. Education or teachers in nonformal educational institutions are members of the community who are devoted and appointed to support the implementation of education, as stated in Chapter 1, General Provisions Article 1 paragraph 5 of the National Education System Law Number 20 of $2003 .^{44}$

Furthermore, non-formal education is classified as non-school education under PP. 73 of 1991. Out-of-school education is education that takes place outside of the classroom, whether it is institutionalized or not. 45 According to PP. 73 of 1991, out-of-school education includes education held outside of schools, both in government and non-government institutions, as well as in the private and community sectors.

Non-formal Islamic education institutions are institutions that provide opportunities for everyone to enrich themselves with science and technology through the concept of lifelong learning (long live education). The emergence of a community-based education paradigm was prompted by the current of modernization, which necessitates democracy in all aspects of human life, including education. As a result, education must be managed decentralizedly in order to provide the greatest possible space for the community while also meeting the needs of Islamic educational institutions.

\footnotetext{
42 Ibid.

43 Muhammad Dahrin, "Peranan Pendidikan Islam Nonformal Terbaru," Scribd, n.d., https://id.scribd.com/document/23945591/Print-Peranan-Pendidikan-IslamNonformal-Terbaru.

44 Ibid.

45 Haidar Putra Daulay, Pendidikan Islam Dalam Sistem Pendidikan Nasional (Medan: IAIN Press, 2002), 167.
} 
Mosques (mushalla, langgar, surau), madrasah diniyah, majlis taklim, alQuran education gardens, Islamic courses, spiritual development agencies, religious consulting bodies, and musabaqah tilawatil the Quran are examples of community-based educational institutions (non-formal/outside of school). 46

\section{Components of Education}

In Islamic educational institutions, there are six components. These components will form interaction patterns and influence each other, but the interaction components are found in educators with all of their abilities and limitations 47 in shaping the character of students, including matters related to religious moderation in students.

According to Ramayulis, education has six components: objectives, educators, students, content/material, methods, and environmental situations.48 Furthermore, Noeng Muhadjir revealed that educational components include: objectives, student subjects, educators, and the environment. Then, according to Aminuddin Rasyad, the essential elements of education are educational materials, students and educators, educational goals, educational methods, educational tools, educational environment, and educational evaluation. ${ }^{49}$

According to some of the opinions expressed above, educational institutions have many components that influence one another. These are the following components: 1) educational material, 2) students and educators, 3) educational goals, 4) how to educate, 5) educational tools, 6) educational environment, and 7) educational evaluation.

At least in this discussion, the author discusses only a few aspects of education that, without a doubt, have a high priority in the formation of religious moderation as a strategic role of educational institutions. Among these elements are:

\section{Components of Educational Objectives}

Educational goals serve as the direction in which educational activities should be directed. With clearly defined objectives, the other components of education and their activities are always guided by the goals, so the

46 Ramayulis, Ilmu Pendidikan Islam, 284.

${ }^{47}$ Supiana, Sistem Pendidikan Madrasah Unggulan (Jakarta: Balitbang \& Diklat Departemen Agama RI, 2008), 17.

${ }^{48}$ Ramayulis, Pengantar Ilmu Pendidikan (Jakarta: Rajawali Press, 2006), 35.

${ }^{49}$ Supiana, Sistem Pendidikan Madrasah Unggulan, 17. 
effectiveness of the educational process is always measured by whether or not they can achieve the goals. ${ }^{50}$

Educational objectives are a critical issue in education. Because without a clear formulation of the purpose of education, actions can be disorganized, aimless, and even lead astray or take wrong turns. As a result, the clear and decisive formulation of goals becomes the core of all pedagogical thinking and philosophical contemplation.. ${ }^{51}$

Based on the explanation of the preceding objectives, it is necessary to formulate religious moderation in the formulation of educational goals. As the foregoing, if the formulation related to religious moderation already exists, it will, of course, produce the derivative that must be implemented as the goal's implementation.

\section{Components of Students}

Students are the most important aspect of educational institutions; without them, educational institutions are meaningless. Students, also known as peseta students, are members of society who attempt to develop themselves through the educational process at certain levels, paths, and types of education. ${ }^{52}$ Then, Ramayulis proposed that students are people who are in a stage of growth and development, both physically and psychologically, and that growth and development are characteristics of a student who requires guidance from an educator. 53

The learning process is primarily focused on teaching students how to achieve predetermined goals. As a result, students must be at the center of all activities during the process of developing planning and learning design. ${ }^{54}$

\section{Components of Educators}

Educators are people who help students improve their knowledge, attitudes, and behavior. ${ }^{55}$ According to Abudin Nata, "teachers are the most

50 Ibid., 18.

51 Kartini Kartono, Pengantar Ilmu Pendidikan Teoritis (Bandung: Mandar Maju, 1992), 204.

52 Ibid., 20.

${ }^{53}$ Ramayulis, Ilmu Pendidikan Islam, 77.

54 Wina Sanjaya, Perencanaan Dan Desain Sistem Pembelajaran (Jakarta: Kencana, 2011), 9.

55 Zakiyah Darajat, Islam Untuk Disiplin Ilmu Pendidikan (Jakarta: Bulan Bintang, 1987), 19. 
important component of education, especially in dealing with various problems related to improving the quality of education". 56

According to Imam al Ghazali, the main task of teachers is to perfect, clean, tune out, and bring the human heart closer to Allah SWT. ${ }^{57}$ An educator is said to be good at formal education if he has academic qualifications and competence as a learning agent, is physically and mentally healthy, and has the ability to realize national education goals. ${ }^{58}$

According to Yedi Purwanto et al, who cited Darmawan's opinion in Soemantri, the education component is responsible for developing students' religious moderation. The campus, as an educational institution, must act as a "water tower" for its people. Every lesson for the community flows from the campus or educational institutions, which must eventually become a center of excellence for development. ${ }^{59}$.

\section{Components of Materials / Contents of Education}

The material or curriculum is something that the teacher must master and plays a critical role in the achievement of educational goals. The curriculum derives from the Greek words curir, which means runner, and curare, which means a place to race. So the term curriculum comes from the world of sports in Ancient Roman times in Greece, and it refers to the distance that runners must travel from the start line to the finish line. ${ }^{60}$

In the world of education, the curriculum can be interpreted in a narrow way or broadly. Narrowly, the curriculum is defined as a number of subjects that must be taken or completed by students in madrasas or universities. $^{61}$ Based on a narrow definition of curriculum, Supiana also emphasized that curriculum in a narrow sense is a number of material or lesson content. Subject matter or content is all messages conveyed by

251.

${ }^{56}$ Abudin Nata, Paradigma Baru Pendidikan Islam (Jakarta: Grasindo, 2003),

17.

${ }^{57}$ Ngainun Naim, Menjadi Guru Inspiratif (Yogyakarta: Pustaka Pelajar, 2013),

58 Supiana, Sistem Pendidikan Madrasah Unggulan, 22.

59 Yedi Purwanto et al., "Internalisasi Nilai Moderasi Melalui Pendidikan Agama Islam Di Perguruan Tinggi Umum," EDUKASI: Jurnal Penelitian Pendidikan Agama Dan Keagamaan 17, no. 2 (August 31, 2019), doi:10.32729/edukasi.v17i2.605.

${ }^{60}$ Hasan Langgulung, Manusia Dan Pendidikan Suau Analisa Psikologi (Jakarta: Pustaka al Husna, 1986), 150.

${ }^{61}$ Supardi, Kinerja Guru (Jakarta: Rajawali Press, 2013), 141. 
educators to students in order to achieve educational goals. ${ }^{62}$ Meanwhile, on a broader basis, Nurdin and Basyiruddin interpreted the curriculum as not limited to subjects, but broader than that; The curriculum is defined as any activity carried out by madrasas in order to influence students in learning to achieve a goal, including learning activities, managing strategies in learning, how to evaluate learning development programs and so on. ${ }^{63} \mathrm{M}$. Arifin, also views "the curriculum as all learning materials that must be presented in the educational process in an institutional system". ${ }^{64}$ In the National Education System Law Number 20 of 2003, Article 1 paragraph 11, explains that the curriculum is a set of plans and arrangements regarding the content and learning materials as well as the methods used as guidelines for the implementation of teaching and learning activities. ${ }^{65}$

Based on the definition of the curriculum provided above, it is possible to conclude that the curriculum is a material or material, subjects, processes, goals, and methods for achieving the goals. When it comes to religious moderation, the curriculum in an educational institution plays a critical role in achieving religious moderation.

\section{Components of Educational Environment}

The educational environment is a physical and temporal space that facilitates the execution of educational activities. The educational process takes place in a setting, whether it is a family setting, a school setting, or a community setting. ${ }^{66}$ Students with varying abilities will develop to their full potential if they are in a supportive environment. A hidden curriculum is an environment that promotes the achievement of educational goals.

\section{DISCUSSION}

In this section of the discussion, the author explains how Islamic educational institutions participate in religious moderation. According to the description in the theoretical study above, Islamic education institutions have at least some participation or role in religious moderation, including:

First, educational institutions have a role to play in developing or revising educational objectives. Educational goals are targets that an

\footnotetext{
62 Supiana, Sistem Pendidikan Madrasah Unggulan, 24.

63 Supardi, Kinerja Guru, 141.

${ }^{64}$ Ramayulis, Ilmu Pendidikan Islam, 151.

65 Undang-Undang Sistem Pendidikan Nasional No. 20 Tahun 2003.

${ }^{66}$ Supiana, Sistem Pendidikan Madrasah Unggulan, 25.
} 
educational institution must meet; without goals, education implementation will become disoriented. The educational purpose serves as a guideline for how the educational process should be carried out and what outcomes are expected. This educational goal is a business standard that can be determined, as well as a business direction that can be pursued and a starting point for achieving other goals. Furthermore, the goal can limit the space for the business to move in order for activities to focus on what is desired, and the most important thing is to be able to provide an assessment or evaluation of educational efforts.

According to TAP. MPR No. II/MPR/1993 on GBHN, the purpose of education is to increase devotion to God Almighty, intelligence, skills, enhance character, strengthen personality, and enhance the spirit of nationality so that humans can develop themselves and are jointly responsible for nation building.

In general, there are four educational goals: a) the general goal of national education is to form Pancasila people, b) institutional objectives, namely the goals that are the responsibility of specific educational institutions to achieve, c) curricular goals, namely the objectives of the field of study or subject, d) instructional objectives, namely the objectives of curriculum materials in the form of learning subjects consisting of main themes and subthemes. The foregoing is also comprised of general and special instructional objectives. $^{67}$

According to the explanation related to educational goals and associated with religious moderation. Schools, as educational institutions, have a role in formulating educational goals based on religious moderation, both in terms of institutional goals and in the order of curricular and instructional goals. In terms of institutional goals, schools can formulate institutional goals by using religious moderation language or terms. Schools or teachers can add words or terms or be based on religious moderation to the setting of curricular goals or course objectives, as well as to the order of specific and general instructional objectives, which are now known as core competencies and basic competencies.

Second, educational institutions have a role to play in providing teachers or educators with both direct and indirect guidance. Teachers have a very high position in the Islamic perspective, so much so that they place one or

67“Pengertian Dan Fungsi Tujuan Pendidikan,” BERBAGI ILMU, accessed February 17, 2021, https://www.rijal09.com/2016/03/pengertian-dan-fungsi-tujuanpendidikan.html. 
two teachers on the same level as the Prophet. ${ }^{68}$ As a result, all actions, actions, attitudes, and words recorded in students' lives must be capable of serving as good examples and role models for all students, as well as the entire community, nation, and state. Teachers play a critical strategic role in controlling all types of differences, including ethnic, skin color, economic, religious, and other differences. As a role model, Luc Reychler states in his theory of peace architecture that controlling religious differences necessitates a number of conditions, including: 1) the existence of an effective and harmonious communication channel that allows the process of discussion, clarification, and correction to the dissemination of information or rumors that has the potential to cause tension be established. 2) the operation of problemsolving institutions, whether formal like courts or informal like customary and religious institutions. 3) The existence of pro-peace figures with influence, resources, and effective strategies for preventing pro-conflict figures from mass mobilizing. 4) a just socio-political structure to support the realization of justice in society; 5) a just socio-political structure to ensure the survival of social integration. ${ }^{69}$

From the conditions stated above, one option is the teacher, who has the ability to break down all differences in race, language, skin color, and ethnicity in fostering a religiously moderate attitude in a school or educational institution.

Third, educational institutions play a role in promoting religious moderation through the material/curriculum and the learning process. When we talk about educational institutions, we are also talking about the learning process. The learning process can not be separated from the world of education because learning and teaching are two interdependent interactions; where there is a learning process, there will inevitably be a teaching process, and the interaction will become educative. According to Habernas, new learning occurs when individuals interact with their surroundings. He categorizes learning into three categories: 1) technical learning, namely learning how to interact correctly with one's natural environment; 2) practical learning, namely learning how to interact correctly with one's social environment, namely with the people around them; 3) emancipatory learning

68 Ahmad Tafsir, Ilmu Pendidikan Dalam Perspektif Islam (Bandung: Remaja Rosdakarya, 1994), 76.

${ }^{69}$ Kementerian Agama RI, Moderasi Beragama, 58. 
(emancipatory learning), namely learning that emphasizes efforts to achieve a high understanding and awareness of one's surroundings. ${ }^{70}$

As an educator, the teacher is tasked with channeling, directing, and motivating students so that they can develop their potential, rather than dictating, forcing, or limiting students' freedom to be creative. Each student possesses a distinct potential (multiple potential).Students' individuality must be utilized and developed in a more positive direction, namely respecting and respecting others in terms of differences. Students can think openly (open thinking) during the learning process, which is thinking about how to respect the right to life, the right to education, the right to express oneself, the right to embrace religion, and the right not to easily blame others. The final outcome of an encounter with another world, religion, and religious cultures will lead students to think more maturely, have a point of view, and understand reality in a variety of ways. ${ }^{71}$

Students, as the nation's next generation, must, of course, be given a broad understanding of how to implement rahmatanlil'alamiin Islam and make Islam a model for associating with others by respecting and respecting all differences. Of course, in order to achieve this, the teacher must set a good example of religious moderation. This implementation can be carried out using precise methods and strategies.

The participation of schools or educational institutions in instilling religious moderation through learning materials is by incorporating religious moderation materials into the subject's material/curriculum. By incorporating religious moderation values into the material or curriculum, religious moderation can be integrated into school materials or curricula. The following are the values of moderation that are intended: (1) The meaning of justice, the value of justice, is "the same," namely equality in rights. A person who walks straight and stances uses only one measurement, never two. ${ }^{72}$ Because of the existence of equality, someone will be able to act fairly, not taking sides with one of the disputants. Justice also entails being able to act on its terms rather than your own. (2) The worth of balance (tawadzun). Equilibrium does not necessitate the equality of content and conditions in order for all parts of the unit to be balanced. It is possible for one part to be small or large, with small

70 Asri Budiningsih, Belajar Dan Pembelajaran (Yogyakarta: Rineka Cipta, 2004), 73-74.

71Zakiyuddin Baidhawy, Pendidikan Agama Berwawasan Multikultural, (Jakarta: Erlangga, 2005), p. 83

72 Fahri and Zainuri, "Moderasi Beragama Di Indonesia," 97. 
and large determined by the function expected of it. $^{73}$, (3) The value of tolerance, Qurays Shihab explained that measuring limits for addition or subtraction tolerances are still acceptable. Tolerance is a deviation that must be done or avoided, or, in other words, a deviation that can still be justified.

Fourth, educational institutions play a role in preparing students to practice religious moderation in the school setting. The school environment teaches students how to interact with one another. The environment has a significant influence on the development of students' attitudes; if the environment is good, it will have a positive influence on student development, and vice versa. The term "school environment" is derived from the word "environment," which means "all around a circle, area, and so on". ${ }^{74}$ Imam Supardi stated that the meaning of the environment is the sum of all objects, whether living or dead, as well as all existing conditions in the occupied space. $^{75}$ Meanwhile, Syamsu Yusuf defines schools as formal educational institutions that systematically carry out guidance, teaching, and training activities to help students develop all of their potential, including moral, spiritual, intellectual, emotional, and social aspects. According to him, the school environment is the sum of all objects, both living and dead, as well as all the conditions that exist in formal educational institutions that carry out educational activities in a systematic manner and assist students in developing their potential. ${ }^{76}$ According to another version, the school environment is a unitary sphere within the scope of formal education that influences the formation of attitudes and the development of students' potential. ${ }^{77}$

Based on the above definition of the school environment, it is possible to conclude that the school environment includes living objects in the form of the closest human beings that surround them, such as family. The family is the primary and first school or environment, because it is the first place where humans gain experience and learn, as well as develop all of their potential. Such as talking, eating, playing, and doing things. Aside from that, humans receive family education beginning in the womb (known as the prenatal period

\footnotetext{
73 Ibid.,

${ }^{74}$ Hoetomo, Kamus Lengkap Bahasa Indonesia (Surabaya: Mitra Pelajar, 2005), 318.

${ }^{75}$ Imam Supardi, Lingkungan Hidup Dan Kelestariannya (Bandung: PT. Alumni, 2003), 2.

76 Yusuf Syamsu, Psikologi Perkembangan Anak Dan Remaja (Bandung: PT. Remaja Rosdakarya, 2001), 54.

77 Ibid.,
} 
in Islam) and continuing through the toddler period (post-nata or pre-school period).

The fundamentals of human personality formation also include all materials, such as a neatly arranged schoolyard environment that is equipped with various material facilities, such as a permanent school fence to keep distractions at bay, safe and comfortable school parking, the development of representative learning spaces, and the arrangement of the school grounds from cleanliness, beauty, and sanitation. The school environment also includes the socio-cultural or community environment surrounding the school, whose position is very important in the world of education because one another is interconnected and needs each other, or in general, the relationship between schools and the community has a goal to be achieved, namely improving the quality of education, which in the end the community will feel the benefits of it. ${ }^{78}$ An unfavorable or unsupportive environment, on the other hand, will have a negative impact on students' potential development and school progress.

Religious moderation, which is the noble ideal of the Indonesian nation, will create a peaceful Indonesian nation, free of conflict and friction, which is essential for a good school environment.

\section{Conclusion}

Religious moderation is a difficult task that must be accomplished in order to foster a peaceful environment on both a local and global scale. Islamic education institutions are educational institutions that study the Quran and Hadiths and play a significant role in promoting moderate religious attitudes among students.

The role or participation of Islamic education institutions in religious moderation is first, to formulate educational goals based on religious moderation, second, to foster religious moderation either directly (direct) or indirectly (indirect), third, to integrate religious moderation materials into subjects, and fourth, to habituate students to the school environment.

Participation of educational institutions in religious moderation for students is the steps that educational institutions must take in order to realize moderate religious attitudes.

78 Tim Dosen Administrasi Pendidikan UPI, Manajemen Pendidikan (Bandung: Alfabeta, 2011), 28. 
46 | AJIS : Academic Journal of Islamic Studies, vol. 6, no. 1, 2021

\section{References}

Ahmadi, Abu, and Nur Uhbiyati. Ilmu Pendidikan Islam. Jakarta: Rineka Cipta, 1991.

Akhmadi, Agus. "Moderasi Beragama dalam Keragaman Islam." Inovasi-Jurnal Diklat Keagamaan 13, no. 2 (April 23, 2019): 45-55.

Anhar, Harizal. "Interaksi Edukatif Menurut Pemikiran Al-Ghazali." Jurnal Ilmiah Islam Futura 13, no. 1 (August 1, 2013): 28-41. doi:10.22373/jiif.v13i1.570.

Ar, Samsul. "Peran Guru Agama Dalam Menanamkan Moderasi Beragama." AlIrfan : Journal of Arabic Literature and Islamic Studies 3, no. 1 (March 27, 2020): 37-51. doi:10.36835/al-irfan.v3i1.3715.

Bafadhol, Ibrahim. "Lembaga Pendidikan Islam di Indonesia." Edukasi Islami: Jurnal Pendidikan Islam 6, no. 11 (October 25, 2017): 14. doi:10.30868/ei.v6i11.95.

Budiningsih, Asri. Belajar Dan Pembelajaran. Yogyakarta: Rineka Cipta, 2004.

Dahrin, Muhammad. "Peranan Pendidikan Islam Nonformal Terbaru." Scribd, n.d. https://id.scribd.com/document/23945591/Print-PerananPendidikan-Islam-Nonformal-Terbaru.

Darajat, Zakiyah. Islam Untuk Disiplin Ilmu Pendidikan. Jakarta: Bulan Bintang, 1987.

Darlis, Ahmad. "Hakikat Pendidikan Islam: Telaah Terhadap Hubungan Pendidikan Informal, Non Formal Dan Formal." JURNAL TARBIYAH 24, no. 1 (August 21, 2017). doi:10.30829/tar.v24i1.131.

Daulay, Haidar Putra. Pendidikan Islam Dalam Sistem Pendidikan Nasional. Medan: IAIN Press, 2002.

Dawing, Darlis. "Mengusung Moderasi Islam Di Tengah Masyarakat Multikultural." Rausyan Fikr: Jurnal Studi Ilmu Ushuluddin Dan Filsafat 13, no. 2 (2017): 225-55. doi:10.24239/rsy.v13i2.266.

Fahri, Mohamad, and Ahmad Zainuri. "Moderasi Beragama Di Indonesia." Intizar 25, no. 2 (2019): 95-100. doi:10.19109/intizar.v25i2.5640.

Fauzi, Ahmad. "Moderasi Islam, Untuk Peradaban Dan Kemanusiaan." JURNAL ISLAM NUSANTARA 2, no. 2 (December 30, 2018): 232-44. doi:10.33852/jurnalin.v2i2.101. 
Goode, William J. Sosiologi Keluarga. Jakarta: Bumi Aksara, 2004.

Hasbullah. Kapita Selekta Pendidikan Islam. Jakarta: PT. Raja Grafindo, 1996.

Hoetomo. Kamus Lengkap Bahasa Indonesia. Surabaya: Mitra Pelajar, 2005.

Kamali, Mohammad Hashim. The Middle Path of Moderation in Islam. Oxford: University Press, 2015.

Kartono, Kartini. Pengantar Ilmu Pendidikan Teoritis. Bandung: Mandar Maju, 1992.

Kementerian Agama RI. Moderasi Beragama. Jakarta: Balitbang dan Diklat Kemenag RI, 2019.

Langgulung, Hasan. Manusia Dan Pendidikan Suau Analisa Psikologi. Jakarta: Pustaka al Husna, 1986.

M. Hanafi, Muchlis. Moderasi Islam. Ciputat: Ikatan Alumni al Azhar dan Pusat Studi al Quran (PSQ), 2013.

Madjid, Nurkholis. Pluralitas Agama; Kerukunan Agama Dalam Keragaman. Jakarta: Kompas Nusantara, 2001.

Misrawi, Zuhairi. Hadratussyaikh Hasyim Asy'ari Moderasi, Keutamaan Dan Kebangsaan. Jakarta: PT. Kompas Media Nusantara, 2010.

Muhajir, Afifuddin. Membangun Nalar Islam Moderat; Kajian Metodologis. Situbondo: Tanwirul Afkar, 2018.

Mujib, Abdul. Ilmu Pendidikan Islam. Jakarta: Kencana, 2008.

Naim, Ngainun. Menjadi Guru Inspiratif. Yogyakarta: Pustaka Pelajar, 2013.

Nata, Abudin. Paradigma Baru Pendidikan Islam. Jakarta: Grasindo, 2003.

Nurlaili. "Metodologi Pendidikan Islam Formal-Informal (Analisa Pendidikan di Rumah dan Sekolah)." At-Ta'lim : Media Informasi Pendidikan Islam 12, no. 1 (March 1, 2019): 152-65. doi:10.29300/attalim.v12i1.1625.

"Pengertian Dan Fungsi Tujuan Pendidikan." BERBAGI ILMU. Accessed February 17, 2021. https://www.rijal09.com/2016/03/pengertiandan-fungsi-tujuan-pendidikan.html.

Purwanto, Yedi, Qowaid Qowaid, Lisa'diyah Ma'rifataini, and Ridwan Fauzi. "Internalisasi Nilai Moderasi Melalui Pendidikan Agama Islam Di Perguruan Tinggi Umum." EDUKASI: Jurnal Penelitian Pendidikan Agama Dan Keagamaan 17, no. 2 (August 31, 2019). doi:10.32729/edukasi.v17i2.605. 
48 | AJIS : Academic Journal of Islamic Studies, vol. 6, no. 1, 2021

Pusat Bahasa Departemen Pendidikan Nasional. Kamus Besar Bahasa Indonesia. Jakarta: PT. Gramedia, 2008.

Ramayulis. Ilmu Pendidikan Islam. Jakarta: Kalam Mulia, 2011.

___. Pengantar Ilmu Pendidikan. Jakarta: Rajawali Press, 2006.

Romlah, Siti. "Sistem Penyelenggaraan Pendidikan Islam Non Formal Di Indonesia." Jurnal Studi Islam: Pancawahana 15, no. 1 (June 22, 2020): $1-14$.

Sanjaya, Wina. Perencanaan Dan Desain Sistem Pembelajaran. Jakarta: Kencana, 2011.

Shihab, Muhammad Quraysh. Wasathiyyah; Wawasan Islam Tentang Moderasi Beragama. Tangerang: Lentera Hati, 2019.

Supardi. Kinerja Guru. Jakarta: Rajawali Press, 2013.

Supardi, Imam. Lingkungan Hidup Dan Kelestariannya. Bandung: PT. Alumni, 2003.

Supiana. Sistem Pendidikan Madrasah Unggulan. Jakarta: Balitbang \& Diklat Departemen Agama RI, 2008.

Syafrudin. Paradigma Tafsir Tekstual Dan Kontekstual; Usaha Memaknai Kembali Pesan al Quran. Yogyakarta: Pustaka Pelajar, 2009.

Syahrir, Sulthan. "Metode Studi Islam Komprehensif Dan Implikasinya Terhadap Corak Pemikiran Aliran-Aliran Dalam Islam.” Analisis: Jurnal Studi Keislaman 19, no. 2 (2019): 339-50. doi:10.24042/ajsk.v19i2.3616.

Syamsu, Yusuf. Psikologi Perkembangan Anak Dan Remaja. Bandung: PT. Remaja Rosdakarya, 2001.

Tafsir, Ahmad. Ilmu Pendidikan Dalam Perspektif Islam. Bandung: Remaja Rosdakarya, 1994.

Tim Dosen Administrasi Pendidikan UPI. Manajemen Pendidikan. Bandung: Alfabeta, 2011.

“TNI Dan Polisi Magelang Jaga Gereja sebagai Antisipasi Dampak Tolikara.” Tribun Jogja, July 25, 2015. https://jogja.tribunnews.com/2015/07/25/tni-dan-polisi-magelangjaga-gereja-sebagai-antisipasi-dampak-tolikara. 